\title{
Osadzeni z niepełnosprawnością fizyczną — w kierunku diagnozy potrzeb
}

\author{
AgNIESZKA NYMŚ-GóRNA* \\ ORCID: 0000-0001-5538-1953 \\ Zakład Penitencjarystyki \\ Uniwersytet im. Adama Mickiewicza w Poznaniu
}

Osadzeni z niepełnosprawnością to dosyć szeroka kategoria. W tym artykule poruszana będzie tematyka wyłącznie niepełnosprawności fizycznej (z pominięciem osób z niepełnosprawnością intelektualną, ze względu na specyfikę tej niepełnosprawności). Dotyczy ona bowiem wad wzroku, słuchu czy narządów ruchu, aczkolwiek może chodzić również o osoby z niepełnosprawnością sprzężoną. Tymczasem każda z tych grup wymaga osobnego dostosowywania oddziaływań. Ponadto czasami pojawiają się wręcz wątpliwości co do zasadności umieszczania takich osób w zakładach karnych.

Samo podejście do niepełnosprawności zmieniało się w ciągu wieków i tak naprawdę nadal podlega nieustannej ewolucji. Największy wpływ na te przeobrażania mają czynniki społeczno-kulturowe, historyczne, geograficzne, poziom wiedzy społeczeństwa oraz system aksjonormatywny. Nade wszystko należy jednak pamiętać, że niepełnosprawność dotyczy drugiego człowieka, a więc jest związana z jego godnością, poczuciem akceptacji oraz empatii ${ }^{1}$.

* Autorka jest stypendystką Fundacji Uniwersytetu im. Adama Mickiewicza w Poznaniu na rok akademicki 2019/2020.

${ }^{1}$ M. Giełda, Pojęcie niepetnosprawności, [w:] M. Giełda, R. Raszewska-Skałecka, Prawno-administracyjne aspekty sytuacji osób niepelnosprawnych w Polsce, Wrocław 2015, S. $17-20$.

Nowa Kodyfikacja Prawa Karnego 53, 2019

(C) for this edition by CNS 
W Unii Europejskiej nie istnieje wspólna, jednolita dla wszystkich państw, definicja niepełnosprawności. Nawet w granicach jednego państwa często korzysta się z kilku definicji jednocześnie, co znacznie utrudnia podejmowane próby uniwersalnego posługiwania się tym pojęciem. Każdy kraj ma też własny, wewnętrzny system procedury orzekania o niepełnosprawności. Dlatego też osoba, która w danym kraju otrzyma orzeczenie o niepełnosprawności, w innym na podstawie tych samych dokumentów i zbieżnej sytuacji życiowej takiego statusu mogłaby już nie otrzymać. W Unii Europejskiej średnio jeden na sześciu obywateli krajów członkowskich to osoba z niepełnosprawnością ${ }^{2}$. W Polsce według danych Głównego Urzędu Statystycznego w 2011 roku mieszkało 4697000 osób z niepełnosprawnością ${ }^{3}$.

Wyróżnia się kilka modeli, z których perspektywy rozpatruje się niepełnosprawność w nieco inny sposób ${ }^{4}$ :

1. model społeczny — niepełnosprawność jest konsekwencją sumy przykrych doświadczeń związanych z różnymi ograniczeniami, na przykład uprzedzeniami, niedostosowaniem do potrzeb transportu publicznego, brakiem odpowiednich udogodnień na otwartym rynku pracy;

2. model medyczny — niepełnosprawność jest spowodowana chorobą lub uszkodzeniem ciała/umysłu;

3. model kulturowy - niepełnosprawność jest definiowana przez kulturę danej społeczności, tutaj duże znaczenie będą miały działania podejmowane przez same osoby z niepełnosprawnością w kontekście kreowania ich wizerunku;

4. model scalony - połączenie modelu społecznego i medycznego, co gwarantuje szerokie ujęcie problematyki (model najczęściej wykorzystywany w pedagogice specjalnej).

Każdy człowiek ma swoje potrzeby, a osób z niepełnosprawnością dotyczy jeszcze dodatkowy katalog potrzeb wynikający z samej niepełno-

2 B. Trębicka-Postrzygacz, O niepetnosprawności $w$ definicjach i regulacjach prawnych $w$ perspektywie inkluzji społecznej, „Student Niepełnosprawny. Szkice i Rozprawy” 2017, nr 17 (10), s. 41-43.

${ }^{3}$ Ludność i gospodarstwa domowe. Stan i struktura społeczno-ekonomiczna. Narodowy Spis Powszechny Ludności i Mieszkań, oprac. A. Wysocka et al., Warszawa 2013, s. 54-55.

${ }^{4}$ M. Giełda, op. cit., s. 21-22. 
sprawności. Jeśli są to osoby, które popełniły przestępstwo i zostały skazane na karę pozbawienia wolności, sytuacja jeszcze bardziej się komplikuje.

Potrzeby te należy interpretować w sensie fizycznym oraz psychologicznym. Mimo że można wskazać pewien wspólny mianownik potrzeb człowieka, należy jednak pamiętać, że potrzeby poszczególnych ludzi różnią się od siebie oraz mogą się zmieniać. Poza tym ludzie mają różne sposoby przekształcania potrzeb w działanie i nie zawsze cechują się one konsekwencją. Motywy tego działania również mogą się zmieniać, a zaspokojenie lub niezaspokojenie potrzeb będzie się wiązało z rozmaitymi reakcjami ${ }^{5}$.

Abraham H. Maslow opracował klasyfikację potrzeb człowieka, rozpoczynając od tych najbardziej podstawowych, dążąc do aktywizacji tych z wyższego rzędu. Wyróżnił potrzeby fizjologiczne, bezpieczeństwa, przynależności i miłości, aktywności i twórczości, samodzielności i autonomii, uznania, nowych wrażeń i doświadczeń, sensu życia, samorealizacji, szczęścia jako ogólnego zadowolenia z życia, wiedzy i rozumienia oraz estetyczne $^{6}$. Na tę hierarchię klarownie nakładają się zadania rozwojowe, co może tworzyć mozaikę wyzwań, które czekają człowieka.

Zadania rozwojowe to z kolei wytyczne, które każda osoba powinna realizować, aby uzyskać spełnienie na danym etapie rozwojowym i tym samym przejść spokojnie na kolejny etap. Robert J. Havighurst opracował jedną z najpopularniejszych klasyfikacji zadań rozwojowych. Według niego źródła tychże zadań leżą w rozwoju biologicznym i potrzebach własnych (z uwzględnieniem aspiracji), a także presji społecznej i kulturowej ${ }^{7}$. Z kategorią zadań rozwojowych wiąże się też teoria Erika H. Eriksona dotycząca wydarzeń rozwojowych i szeroko pojętych wpływów społecznych ${ }^{8}$. Osadzonych oczywiście dotyczą przede wszystkim zadania rozwojowe okresu dorosłości, jednak na różnym jej etapie. Ich wypełnianie w związku z odbywaniem kary może być w pewnym stopniu ograniczone.

5 A. Miler-Zawodniak, Teorie potrzeb jako współczesne teorie motywacji, „Obronność - Zeszyty Naukowe Wydziału Zarządzania i Dowodzenia Akademii Obrony Narodowej" 2012, nr 4, s. 102.

6 Z. Dąbrowski, F. Kulpiński, Pedagogika opiekuńcza. Historia, teoria, terminologia, Olsztyn 2000, s. 123.

7 A. Brzezińska, Społeczna psychologia rozwoju, Warszawa 2007, s. 234.

8 Ibidem. 
Pojęciem niezwykle użytecznym dla opisu zmian jakościowych okresu dorosłości i powiązanym z kategorią potrzeb jest motywacja (pojmowana jako zespół dążeń i oczekiwań warunkujących określone zachowania $^{9}$ ), ponieważ możemy ją łączyć z celami, do których dana jednostka dąży zarówno w najbliższym, jak i dalszym czasie.

Rozpoznając sytuację zdrowotną skazanych, należy wyjść od tego, że zgodnie z polskimi uregulowaniami prawnymi skazanemu zapewnia się bezpłatne świadczenia zdrowotne, leki i artykuły sanitarne. Świadczenia zdrowotne udzielane są osadzonym w pierwszej kolejności przez podmioty lecznicze dla osób pozbawionych wolności ${ }^{10}$. W uzasadnionych przypadkach skazany może także uzyskać zgodę na leczenie na swój koszt, przez wybranego przez siebie lekarza oraz na korzystanie z dodatkowych leków i środków medycznych ${ }^{11}$. Nie ma jednak możliwości samodzielnego podejmowania decyzji w tym zakresie, a wszystko musi odbywać się na drodze proceduralnej.

Ochrona zdrowia w jednostkach penitencjarnych w Polsce opiera się na kilku bardzo ważnych aktach prawnych. Należy przede wszystkim wymienić: Europejskie reguły więzienne (zwłaszcza część III) ${ }^{12}$, Kodeks karny wykonawczy ${ }^{13}$, rozporządzenie Ministra Sprawiedliwości z dnia 31 października 2003 roku w sprawie szczegółowych zasad, zakresu i trybu udzielania świadczeń zdrowotnych osobom pozbawionym wolności przez zakłady opieki zdrowotnej dla osób pozbawionych wolności ${ }^{14}$ oraz rozporządzenie Ministra Sprawiedliwości i Ministra Zdrowia z dnia 10 września 2003 roku w sprawie szczegółowych zasad, zakresu i trybu współdziałania zakładów opieki zdrowotnej ze służbą zdrowia

9 S.M. Kosslyn, R.S. Rosenberg, Psychologia. Mózg - człowiek - świat, Kraków 2006, s. 454.

10 Ustawa z dnia 6 czerwca 1997 roku - Kodeks karny wykonawczy (Dz.U. z 2017 r. poz. 665), art. 115 § 1, http://prawo.sejm.gov.pl/isap.nsf/DocDetails.xsp?id=WDU19970900557 (dostęp: 20.05.2019).

11 Dz.U. z 2017 r. poz. 665, art. 115 § 1.

12 Ustalone przez Komitet Ministrów Rady Europy, Rekomendacja Rec (2006) 2, http:/www.bip.sw.gov.pl/SiteCollectionDocuments/CZSW/prawaczl/document.pdf (dostęp: 20.05.2019).

13 Dz.U. z 2017 r. poz. 665.

14 Dz.U. z 2003 r. Nr 204, poz. 1985, http://prawo.sejm.gov.pl/isap.nsf/DocDetails. xsp?id=WDU20032041985 (dostęp: 20.05.2019). 
w zakładach karnych i aresztach śledczych w zapewnieniu świadczeń zdrowotnych osobom pozbawionym wolności ${ }^{15}$.

Zakłady opieki zdrowotnej dla osadzanych udzielają świadczeń zdrowotnych, szczególnie tych związanych z badaniem i poradą lekarską, leczeniem, badaniem i terapią psychologiczną, rehabilitacją leczniczą, opieką nad kobietami w czasie ciąży, porodu i połogu oraz nad noworodkami, badaniem diagnostycznym (w tym analityką medyczną), pielęgnacją chorych i działaniami profilaktycznymi (w tym szczepieniami ochronnymi), badaniem i leczeniem stomatologicznym (w tym protetyką), a także orzekaniem i opiniowaniem o stanie zdrowia ${ }^{16}$. Każdy osadzony podlega badaniom wstępnym (po przyjęciu do jednostki penitencjarnej), okresowym (radiologiczne badanie klatki piersiowej) i kontrolnym (przed transportami i zwolnieniem z jednostki) ${ }^{17}$.

Należy pamiętać, że potrzeby osób z niepełnosprawnością fizyczną będą trochę inne niż pozostałych skazanych i będą dotyczyły chociażby dostosowywania do ich potrzeb, wynikających z niepełnosprawności, propozycji oddziaływań penitencjarnych, rozwiązań organizacyjnych, warunków socjalno-bytowych, likwidacji barier architektonicznych, dostępu do leków przeciwbólowych, stałej rehabilitacji, konsultacji specjalistycznych oraz monitorowania stanu zdrowia. Oprócz tego będą się też oczywiście pojawiały problemy codzienne, które dotyczą wszystkich osadzonych, jak choćby konsultacje listów, które skazani otrzymują z sądu, czy przygotowywanie rozmaitych formalnych wniosków. Skazani często oczekują również zwykłej rozmowy, nawet o błahych sprawach, która daje im możliwość oderwania się chociaż na chwilę od izolacyjnej rzeczywistości.

Biuro Rzecznika Praw Obywatelskich (BRPO) już w 2013 roku zwracało się do ówczesnego Dyrektora Generalnego Służby Więziennej z prośbą o zwrócenie szczególnej uwagi na osoby z niepełnosprawnością fizyczną w jednostkach penitencjarnych (zwłaszcza pod względem swobody poruszania się) $)^{18}$. BRPO powoływało się na zapisy zawarte w Kon-

15 Dz.U. z 2003 r. Nr 171, poz. 1665, http://prawo.sejm.gov.pl/isap.nsf/DocDetails. xsp?id=WDU20031711665 (dostęp: 20.05.2019).

16 Dz.U. z 2003 r. Nr 204, poz. 1985, § 1.

17 Dz.U. z 2003 r. Nr 204, poz. 1985, § 2-5.

18 http://www.sprawy-generalne.brpo.gov.pl/pdf/2013/03/727955/1763571.pdf (dostęp: 28.05.2019). 
wencji ONZ o prawach osób niepełnosprawnych; sprawę monitorował Zespół Krajowego Mechanizmu Prewencji ${ }^{19}$. Aktualnie w niektórych jednostkach penitencjarnych dla funkcjonariuszy Służby Więziennej dodatkowo organizuje się specjalnie szkolenia, podczas których funkcjonariusze zapoznają się ze sposobami postępowania z osobami z niepełnosprawnością fizyczną ${ }^{20}$. Warto też wspomnieć, że istnieje akt prawny, w którym wyraźnie zaznaczone jest, które jednostki penitencjarne są przygotowywane do przyjmowania osób z niepełnosprawnościami ${ }^{21}$. Niestety niektórych jednostek (choćby dlatego, że są bardzo stare) nie można zmodernizować w taki sposób, aby zapewnić w nim odpowiednie warunki osobom z niepełnosprawnością fizyczną.

Oddziaływania penitencjarne w dużym stopniu zależą również od systemu, w którym skazany odbywa karę pozbawienia wolności. Polski system penitencjarny wyróżnia trzy systemy wykonywania kary: zwykły, terapeutyczny oraz programowanego oddziaływania. W systemie zwykłym osadzony może skorzystać z dostępnego w danej jednostce penitencjarnej zatrudnienia, nauczania, zajęć kulturalno-oświatowych i sportowych ${ }^{22}$. Na innych zasadach funkcjonuje już osadzony w systemie programowanego oddziaływania - tutaj obligatoryjnie odbywają karę osadzeni młodociani. Mogą z niego skorzystać również pozostali osadzeni, którzy po przedstawieniu im projektu programu oddziaływania wyrażą zgodę na współpracę w jego opracowaniu, a później wykonaniu. Jeśli osadzony nie wywiązuje się ze swoich zadań, zostaje przeniesiony do systemu zwykłego. W projektowanych oddziaływaniach uwzględnia się przede wszystkim: zatrudnienie, edukację, kontakty z bliskimi, zagospodarowanie czasu wolnego, zasady wykonywania obowiązków, a także inne kwestie istotne dla późniejszego procesu readaptacji społecznej. Programy te podlegają okresowej kontroli i mogą się zmieniać23. Natomiast w systemie terapeutycznym karę odbywają skazani z niepsy-

19 https://www.rpo.gov.pl/pl/content/osoby-z-niepelnosprawnoscia-fizyczna-wwiezieniach-art-14 (dostęp: 28.05.2019).

20 https://www.sw.gov.pl/aktualnosc/Postepowanie-z-osobami-niepelnosprawnymifizycznie (dostęp: 28.05.2019).

$21 \mathrm{https}: / /$ sw.gov.pl/strona/statystyka-przeznaczenie-zk-i-as (dostęp: 28.05.2019).

22 Dz.U. z 2017 r. poz. 665, art. 98.

23 Dz.U. z 2017 r. poz. 665, art. 95. 
chotycznymi zaburzeniami psychicznymi, w tym przestępcy skazani za przestępstwa przeciwko wolności seksualnej (art. 197-203 Kodeksu karnego), z niepełnosprawnością intelektualną, z uzależnieniami (szczególnie od alkoholu lub innych środków odurzających albo psychotropowych) oraz skazani z niepełnosprawnościami fizycznymi, jeśli obecny stan zdrowia tych osadzonych wymaga oddziaływania specjalistycznego (w tym opieki psychologicznej, lekarskiej lub rehabilitacyjnej) ${ }^{24}$. Wykonywanie kary w tym systemie uwzględnia w postępowaniu $\mathrm{z}$ osadzanym przeciwdziałanie pogłębianiu się patologicznych cech osobowości, przywracanie równowagi psychicznej, a także kształtowanie zdolności współżycia społecznego i przygotowanie do samodzielnej egzystencji po odbyciu kary. Wykonywanie kary dostosowuje się do potrzeb skazanego, w szczególności w zakresie leczenia czy zaleceń higieniczno-sanitarnych. Bierze się również pod uwagę możliwość zatrudnienia w systemie pracy chronionej. Jeżeli stwierdza się, że skazany nie wymaga już oddziaływań specjalistycznych, przenosi się go do odpowiedniego sytemu wykonywania kary ${ }^{25}$.

Wykonywanie kary pozbawienia wolności w systemie terapeutycznym odbywa się na oddziałach o konkretnej specjalizacji, aby oddziaływania te mogły być dostosowane do potrzeb skazanych. Na oddziałach terapeutycznych realizowane są specjalistyczne programy usprawniające funkcjonowanie poznawcze i społeczne, treningi kompetencji interpersonalnych, treningi relaksacyjne czy aktywizacja ruchowa. Oprócz tego przygotowywana jest oferta zajęć kulturalno-oświatowych, artystycznych, sportowych, terapii zajęciowej oraz zatrudnienia ${ }^{26}$. Zajęcia proponowane są w formie indywidualnej lub grupowej. Ponadto należy pamiętać o pomocy i wsparciu ze strony współwięźniów. Odpowiednie osadzenie, które jest niezwykle odpowiedzialnym zadaniem wychowawców, ma tutaj bardzo duże znaczenie.

24 Dz.U. z 2017 r. poz. 665, art. $96 \S 1$.

25 Dz.U. z 2017 r. poz. 665, art. 97.

${ }^{26}$ A. Purczyński, Wybrane aspekty funkcjonowania oddziału terapeutycznego dla skazanych z niepsychotycznymi zaburzeniami psychicznymi lub upośledzonych umysłowo i oddziału terapeutycznego dla skazanych uzależnionych od środków odurzających lub psychotropowych w zakładzie karnym w Rawiczu, [w:] Pomoc postpenitencjarna w kontekście strategii działań resocjalizacyjnych, red. B. Skafiriak, Kraków 2007, s. 119-126. 
Próbując sobie wyobrazić funkcjonowanie systemu terapeutycznego, warto odwołać się do informacji statystycznej przygotowywanej okresowo przez Centralny Zarząd Służby Więziennej. Średnio w 2018 roku populacja więzienna wyniosła 74077 osób $^{27}$. W ubiegłym roku (stan na 31 grudnia 2018 roku) liczba skazanych zakwalifikowanych do oddziałów terapeutycznych i przebywających w tych oddziałach wyniosła $3172^{28}$ (dla porównania w 2017 roku było to 3229 osób, w tym 180 kobiet) ${ }^{29}$. Osób z niepsychotycznymi zaburzeniami psychicznymi lub niepełnosprawnością intelektualną było 1552, z czego 355 osób miało zdiagnozowane zaburzenia preferencji seksualnych ${ }^{30}$; osób uzależnionych od środków odurzających lub psychotropowych było wówczas 512, natomiast uzależnionych od alkoholu - 1108 ${ }^{31}$. Osób zakwalifikowanych do oddziałów terapeutycznych, a przebywających poza tymi oddziałami było 854 , w tym 42 kobiety $^{32}$. W populacji więziennej wyróżnia się jeszcze grupę osadzonych zakwalifikowanych do systemu terapeutycznego poza oddziałem, których łącznie było wówczas 728 (w tym 56 kobiet) ${ }^{33}$. Tylko jedna osoba z niepełnosprawnością fizyczną została zakwalifiko-

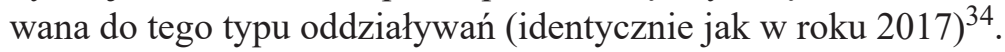

Spoglądając na statystyki, łatwo dostrzec, że mimo iż system penitencjarny przewiduje możliwość osadzania osób z niepełnosprawnością fizyczną w systemie terapeutycznym, praktyka penitencjarna ukazuje jed nak coś zgoła innego. System terapeutyczny daje możliwość bardziej zindywidualizowanych oddziaływań oraz większego dostosowania oddziaływań do potrzeb. W wypadku osób z niepełnosprawnością jest to niezmiernie istotne. Polski system penitencjarny nie dysponuje też oddziałami w ramach systemu terapeutycznego, które byłyby stworzone wyłącznie dla osób z niepełnosprawnością fizyczną. Być może Służba Więzienna uznaje, że po prostu nie ma takiej potrzeby. Oczywiście w systemie zwykłym oraz

\footnotetext{
27 http://www.sw.gov.pl/strona/statystyka-roczna (dostęp: 25.05.2019).

28 Ibidem.

29 Ibidem.

30 Ibidem.

31 Ibidem.

32 Ibidem.

33 Ibidem.

34 Ibidem.
} 
programowanego oddziaływania również istnieje możliwość szczególnego zwrócenia uwagi na potrzeby skazanych z niepełnosprawnością fizyczną, a funkcjonariusze Służby Więziennej starają się tak organizować swoją służbę, aby dostrzec potrzeby, możliwości i ograniczenia tej szczególnej grupy osadzonych, niemniej jednak system terapeutyczny może wykazywać pewien niewykorzystany w tym zakresie potencjał.

Służba Więzienna stanie niedługo przed kolejnym poważnym wyzwaniem, ponieważ wraz ze starzejącym się społeczeństwem do jednostek penitencjarnych trafiać też będzie coraz więcej osób po przebytych ciężkich chorobach, z chorobami przewlekłymi oraz z niepełnosprawnościami. Będzie się to wiązało w pewnym stopniu z reorganizacją codziennej pracy penitencjarnej. Wkrótce będzie też więc trzeba podjąć refleksję nad konkretnymi rozwiązaniami na większą skalę, które będzie można zaproponować więziennej służbie zdrowia, ponieważ to właśnie ona podejmuje kluczowe decyzje w kwestii leczenia i rehabilitacji osadzonych.

Podsumowując, warto przytoczyć jeden z artykułów Powszechnej deklaracji praw człowieka: ,wszyscy ludzie rodzą się wolni i równi w swej godności i w swych prawach. Są oni obdarzeni rozumem i sumieniem i powinni postępować wobec innych w duchu braterstwa"35.

\section{Bibliografia}

Brzezińska A., Społeczna psychologia rozwoju, Warszawa 2007.

Dąbrowski Z., Kulpiński F., Pedagogika opiekuńcza. Historia, teoria, terminologia, Olsztyn 2000.

Giełda M., Pojęcie niepetnosprawności, [w:] M. Giełda, R. Raszewska-Skałecka, Prawno-administracyjne aspekty sytuacji osób niepetnosprawnych w Polsce, Wrocław 2015. Kosslyn S.M., Rosenberg R.S., Psychologia. Mózg — człowiek — świat, Kraków 2006.

Ludność i gospodarstwa domowe. Stan i struktura spoteczno-ekonomiczna. Narodowy Spis Powszechny Ludności i Mieszkań, oprac. A. Wysocka, S. Szefler, R. Antczak, M. Bielska, A. Piszcz, Warszawa 2013.

Miler-Zawodniak A., Teorie potrzeb jako wspótczesne teorie motywacji, „Obronność Zeszyty Naukowe Wydziału Zarządzania i Dowodzenia Akademii Obrony Narodowej" 2012, nr 4.

35 https://amnesty.org.pl/wp-content/uploads/2016/04/Powszechna_Deklaracja Praw_Czlowieka.pdf (dostęp: 28.05.2019). 
Purczyński A., Wybrane aspekty funkcjonowania oddziału terapeutycznego dla skazanych z niepsychotycznymi zaburzeniami psychicznymi lub upośledzonych umystowo i oddzialu terapeutycznego dla skazanych uzależnionych od środków odurzajacych lub psychotropowych $w$ zaktadzie karnym $w$ Rawiczu, [w:] Pomoc postpenitencjarna w kontekście strategii działań resocjalizacyjnych, red. B. Skafiriak, Kraków 2007.

Trębicka-Postrzygacz B., O niepetnosprawności $w$ definicjach i regulacjach prawnych w perspektywie inkluzji społecznej, „Student Niepełnosprawny. Szkice i Rozprawy” 2017, nr 17 (10).

\section{Źródła internetowe}

https://amnesty.org.pl/wp-content/uploads/2016/04/Powszechna_Deklaracja_Praw_Czlowieka.pdf.

https://www.rpo.gov.pl/pl/content/osoby-z-niepelnosprawnoscia-fizyczna-w-wiezieniachart-14.

http://www.sprawy-generalne.brpo.gov.pl/pdf/2013/03/727955/1763571.pdf.

https://www.sw.gov.pl/aktualnosc/Postepowanie-z-osobami-niepelnosprawnymi-fizycznie. https://www.sw.gov.pl/strona/statystyka-przeznaczenie-zk-i-as.

https://www.sw.gov.pl/strona/statystyka-roczna.

\section{Prisoners with physical disabilities - towards the diagnosis of needs}

\section{Summary}

Among the prison population in Poland there are also people with disabilities. The text will focus on physical disability. Convicts with physical disabilities constitute a group that, in penitentiary reality, is faced with many difficulties. Specialised interactions should be directed towards them. Prison Service officers try to minimise factors that may adversely affect the functioning of people with physical disabilities in prisons and pre-trial detention centres. The purpose of this article is to draw attention to prisoners with a physical disability and the specificity of their needs in penitentiary units.

Keywords: disability, prison, offender, isolation, therapeutic system. 